\title{
Observation of dominance of swells over wind seas in the coastal waters of the Gulf of Mannar, India
}

\author{
M. M. Amrutha and V. Sanil Kumar \\ Ocean Engineering Division, CSIR-National Institute of Oceanography (Council of Scientific and Industrial Research), \\ Dona Paula, Goa 403 004, India \\ Correspondence to: V. Sanil Kumar (sanil@ nio.org)
}

Received: 23 March 2017 - Discussion started: 4 May 2017

Revised: 9 August 2017 - Accepted: 11 August 2017 - Published: 15 September 2017

\begin{abstract}
Wind seas typically dominate over swell seas in coastal gulfs. Waves measured at a location having a water depth of $12 \mathrm{~m}$ in the near-shore waters of the Gulf of Mannar during a 1-year period (1 May 2015 to 30 April 2016) are used to examine the predominance of wind seas and swells through spectral characterization. The study shows that even though the location is in a gulf, the annual average value ( $\sim 0.84 \mathrm{~m}$ ) of the significant wave height in this area is comparable to that along the coastal waters of the Indian subcontinent, but the annual maximum value $(\sim 1.7 \mathrm{~m})$ recorded is much less than that ( 3 to $5 \mathrm{~m}$ ) observed in those regions. Also, large seasonal variations are not observed in the wave height. The waves of the study region are under the control of sea breeze, with the maximum in the late evening hours and the minimum in the early morning hours. A $5 \%$ increase in the forcing wind field during the monsoon period improved the comparison statistics between the model wave height and the measured values. A total of $53 \%$ of the surface height variance in the study area is a result of swells from the southeast and south, and the remainder are wind seas from the east and southeast.
\end{abstract}

\section{Introduction}

The Gulf of Mannar (GoM) connects the Arabian Sea in the south to the Palk Bay in the north. Palk Bay is a shallow basin with a maximum water depth of $\sim 13 \mathrm{~m}$ and connects to the Bay of Bengal at its northeastern end (Fig. 1). The western region of the GoM is a marine biosphere reserve and slight changes in the waves and meteorological parameters will have large impacts in this area. The seasonal reversal of the monsoon winds in the north Indian Ocean (Wyrtki, 1971) induces changes in the directionality of the surface waves (Sanil Kumar et al., 2012). The winds are from the southwest in the Indian summer monsoon which lasts from June to September and from the northeast during October to January (winter monsoon). As over the rest of India, the winds in the GoM too reverse with the season (Fig. 2). Winds over the region are much stronger in the summer monsoon $\left(\sim 5-7 \mathrm{~m} \mathrm{~s}^{-1}\right)$ than those during the winter monsoon $(\sim 3-$ $5 \mathrm{~m} \mathrm{~s}^{-1}$ ). Over this region, the winds during February-May are weak with a seasonal average value less than $3 \mathrm{~m} \mathrm{~s}^{-1}$.

Arena and Guedes Soares (2009) grouped the sea states with bimodal spectra in three sets, i.e., swell dominated seas, wind-sea-dominated seas and mixed seas based on the ratio of the significant wave height of the swells and the wind seas. Generally, the swells propagating from distant storms and the local wind seas comprise the waves in the open ocean (Hanson and Phillips, 1999). Wind seas dominate in coastal regions, bays and gulfs (Hwang et al., 2011). When the spectrum is bimodal, the wind seas and the swells can have different directions and can alter the direction of the littoral drift. The high-frequency wave components govern the momentum flux between the ocean and atmosphere (Cavaleri et al., 2012). The long-period waves cause problems for navigation and offshore operations, and induce large motion on moorings (McComb et al., 2009); hence, it is necessary to know the occurrence of long-period waves at a location. Recently, many studies identified long-period waves in the eastern Arabian Sea (Sanil Kumar et al., 2012; Glejin et al., 2016; Amrutha et al., 2017). Sanil Kumar et al. (2003) observed that, in the Indian waters, the wave energy spectra contain multiple peaks for about $60 \%$ of the year and when the signifi- 
Table 1. Studies on waves in Indian waters based on measured wave data covering 1 year and above.

\begin{tabular}{|c|c|c|c|c|c|}
\hline Location & Position & $\begin{array}{r}\text { Water } \\
\text { depth }(m)\end{array}$ & Period of data used & Aspects studied & Reference \\
\hline \multirow[t]{2}{*}{$\begin{array}{l}\text { Ratnagiri, eastern } \\
\text { Arabian Sea }\end{array}$} & \multirow[t]{2}{*}{$\begin{array}{r}16.980^{\circ} \mathrm{N} \\
73.258^{\circ} \mathrm{E}\end{array}$} & \multirow[t]{2}{*}{13} & $\begin{array}{l}1 \text { January } 2011- \\
31 \text { December } 2011\end{array}$ & $\begin{array}{l}\text { Short-term statistics } \\
\text { of waves }\end{array}$ & $\begin{array}{l}\text { Amrutha and } \\
\text { Sanil Kumar (2014) }\end{array}$ \\
\hline & & & $\begin{array}{l}1 \text { May } 2010- \\
30 \text { April } 2012\end{array}$ & $\begin{array}{l}\text { Seasonal and annual variations } \\
\text { in waves, role of sea breeze } \\
\text { and land breeze on waves }\end{array}$ & $\begin{array}{l}\text { Glejin et al. } \\
(2013)\end{array}$ \\
\hline $\begin{array}{l}\text { Eastern } \\
\text { Arabian Sea }\end{array}$ & $\begin{array}{r}16.980^{\circ} \mathrm{N} \\
73.258^{\circ} \mathrm{E} \\
14.822^{\circ} \mathrm{N} \\
74.052^{\circ} \mathrm{E} \\
14.304^{\circ} \mathrm{N} \\
74.391^{\circ} \mathrm{E}\end{array}$ & $\begin{array}{r}13 \\
15 \\
9\end{array}$ & $\begin{array}{l}1 \text { January } 2011- \\
31 \text { December } 2012\end{array}$ & $\begin{array}{l}\text { Characteristics of } \\
\text { long-period swells }\end{array}$ & Glejin et al. (2017) \\
\hline $\begin{array}{l}\text { Karwar, eastern } \\
\text { Arabian Sea }\end{array}$ & $\begin{array}{r}14.822^{\circ} \mathrm{N} \\
74.052^{\circ} \mathrm{E}\end{array}$ & 15 & $\begin{array}{l}1 \text { January } 2011- \\
31 \text { December } 2015\end{array}$ & $\begin{array}{l}\text { Interannual variations } \\
\text { wave spectra }\end{array}$ & $\begin{array}{l}\text { Anjali Nair and } \\
\text { Sanil Kumar (2017) }\end{array}$ \\
\hline $\begin{array}{l}\text { Honnavar, eastern } \\
\text { Arabian Sea }\end{array}$ & $\begin{array}{r}14.304^{\circ} \mathrm{N} \\
74.391^{\circ} \mathrm{E} \\
14.307^{\circ} \mathrm{N} \\
74.291^{\circ} \mathrm{E}\end{array}$ & $\begin{array}{r}9 \\
30\end{array}$ & $\begin{array}{l}1 \text { January } 2009- \\
31 \text { December } 2015 \\
18 \text { April 2014- } \\
18 \text { August 2014 } \\
1 \text { June 2015- } \\
31 \text { July } 2015\end{array}$ & $\begin{array}{l}\text { Seasonal variation in } \\
\text { wave characteristics and } \\
\text { spatial and temporal variations } \\
\text { of wave energy }\end{array}$ & $\begin{array}{l}\text { Amrutha and } \\
\text { Sanil Kumar (2016) }\end{array}$ \\
\hline $\begin{array}{l}\text { Off Dhanushkodi, } \\
\text { Gulf of Mannar }\end{array}$ & $\begin{array}{l}9.113^{\circ} \mathrm{N} \\
79.407^{\circ} \mathrm{E}\end{array}$ & 12 & $\begin{array}{l}9 \text { February 2010- } \\
31 \text { March } 2011\end{array}$ & $\begin{array}{l}\text { Seasonal variations in wave } \\
\text { characteristics and wave spectra }\end{array}$ & $\begin{array}{l}\text { Gowthaman } \\
\text { et al. (2013) }\end{array}$ \\
\hline $\begin{array}{l}\text { Off Dhanushkodi, } \\
\text { Palk Bay }\end{array}$ & $\begin{array}{l}9.319^{\circ} \mathrm{N} \\
79.434^{\circ} \mathrm{E}\end{array}$ & 12 & $\begin{array}{l}9 \text { February 2010- } \\
31 \text { March } 2011\end{array}$ & $\begin{array}{l}\text { Seasonal variations in wave } \\
\text { characteristics and wave spectra }\end{array}$ & $\begin{array}{l}\text { Gowthaman } \\
\text { et al. (2013) }\end{array}$ \\
\hline $\begin{array}{l}\text { Puducherry, western } \\
\text { Bay of Bengal }\end{array}$ & $\begin{array}{r}11.924^{\circ} \mathrm{N} \\
79.851^{\circ} \mathrm{E}\end{array}$ & 15 & $\begin{array}{l}1 \text { January } 2009- \\
29 \text { December } 2011\end{array}$ & $\begin{array}{l}\text { Seasonal and annual } \\
\text { variations in monsoon- } \\
\text { and cyclone-induced waves; } \\
\text { influence of sea and } \\
\text { land breezes on waves }\end{array}$ & $\begin{array}{l}\text { Johnson et } \\
\text { al. (2013) }\end{array}$ \\
\hline $\begin{array}{l}\text { Gangavaram, western } \\
\text { Bay of Bengal }\end{array}$ & $\begin{array}{r}17.633^{\circ} \mathrm{N} \\
83.267^{\circ} \mathrm{E}\end{array}$ & 18 & $\begin{array}{l}1 \text { January } 2010- \\
31 \text { December } 2010\end{array}$ & $\begin{array}{l}\text { Spectral wave characteristics } \\
\text { and seasonal variations }\end{array}$ & $\begin{array}{l}\text { Sanil Kumar } \\
\text { et al. (2014) }\end{array}$ \\
\hline $\begin{array}{l}\text { Gopalpur, northern } \\
\text { Bay of Bengal }\end{array}$ & $\begin{array}{r}19.258^{\circ} \mathrm{N} \\
84.907^{\circ} \mathrm{E}\end{array}$ & 23 & $\begin{array}{l}1 \text { June } 2008- \\
31 \text { May } 2009\end{array}$ & $\begin{array}{l}\text { Variations in wind-sea } \\
\text { and swell characteristics }\end{array}$ & $\begin{array}{l}\text { Patra et al. } \\
\text { (2016) }\end{array}$ \\
\hline
\end{tabular}

cant wave height $\left(H_{\mathrm{m} 0}\right)$ is higher than $2 \mathrm{~m}$, they are generally single-peaked. The multi-peaked wave spectra observed in the coastal region of India are largely dominated by swells (Sanil Kumar et al., 2003). Most of the studies in the Indian waters are in the eastern Arabian Sea (Sanil Kumar et al., 2003, 2012; Glejin et al., 2016; Amrutha et al., 2017; Anjali Nair and Sanil Kumar, 2017) and the western Bay of Bengal (Sundar, 1986; Nayak et al., 2013; Patra and Bhaskaran, 2016). The studies on waves in Indian waters based on measured wave data covering 1 year and above are presented in Table 1. Based on 1-year measured data, Gowthaman et al. (2013) observed that swells are dominant in the northern GoM from January to April and the wind sea dominates in the remaining period of the year. Due to the lack of mea- surements, our knowledge of the wave characteristics in the western part of the GoM is poor. Hence, in this paper, we describe the wave characteristics based on 1-year measured wave data in the western GoM. Apart from describing the seasonal variations, the present study identifies the predominant wave systems in the western GoM. The interannual variation in wind-sea and swell percentage in the surface variance based on numerical model results is studied at $8^{\circ} \mathrm{N}$, $78.25^{\circ} \mathrm{E}$. The change in wind-sea and swell percentage during 1 year along the longitude $78.25^{\circ} \mathrm{E}$ when the waves propagate from 7 to $8.5^{\circ} \mathrm{N}$ in the GoM is also examined.

The paper is structured as follows. In Sect. 2, the data used in the study and the details of numerical model and validation are described. Section 3 includes the results. First, wave 


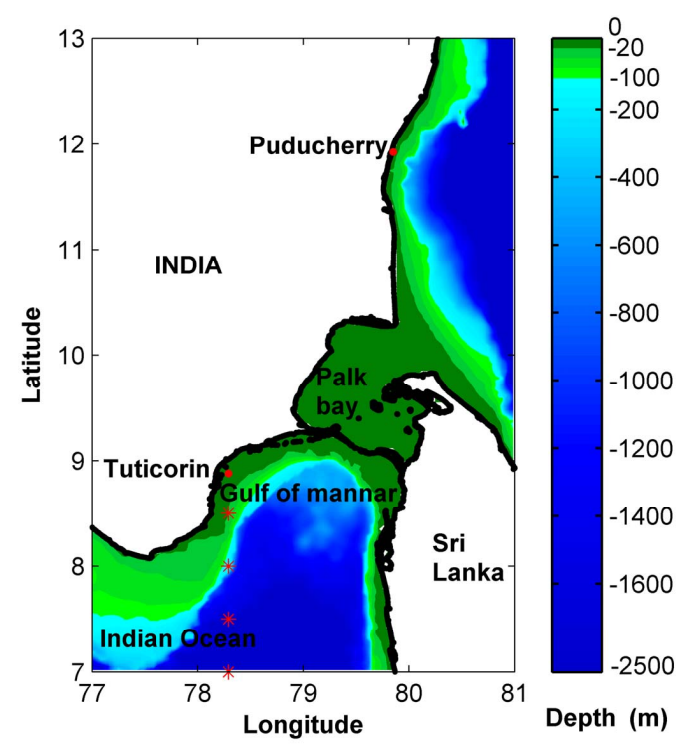

Figure 1. The location of the Waverider buoy mooring in the region of interest in the Gulf of Mannar. The bathymetry is from ETOPO1 (1 arcmin) global relief model (Amante and Eakins, 2009). The star symbols indicate the points considered for studying the percentage change in swells.

parameter statistics are introduced for subsequent use. Second, wave spectral characteristics are presented. Third, the interannual variations are presented based on model data and the results are discussed. The summary of the study is given in Sect. 4.

\section{Data and methods}

\subsection{Data}

This study uses waves measured from 1 May 2015 to 30 April 2016 in the western GoM at a location (latitude $8^{\circ} 52^{\prime} 52^{\prime \prime} \mathrm{N}$; longitude $78^{\circ} 17^{\prime} 44^{\prime \prime} \mathrm{E}$ ) having a water depth of $12 \mathrm{~m}$. The wave data are recorded in a moored directional Waverider buoy continuously at $1.28 \mathrm{~Hz}$ for a 1 -year period. Heave is measured with $1 \mathrm{~cm}$ resolution and with $3 \%$ accuracy. A moored wave buoy may travel around a large crest in a short-crested sea or even be dragged through a large crest if it reaches the limit of its mooring line (Whittaker et al., 2016). Additionally, the Lagrangian buoy motion will still affect the wave measurements of an idealized buoy capable of perfectly following the free surface motions. Although the linear contributions to the free surface elevation measured by a surface-following and fixed sensor are equal, it is generally assumed that this Lagrangian motion will prevent the buoy from measuring the second harmonic component of steep deep-water waves obvious on a wave staff record (Longuet-Higgins, 1986). These effects are not considered in the present study. The wave spectrum is estimated from
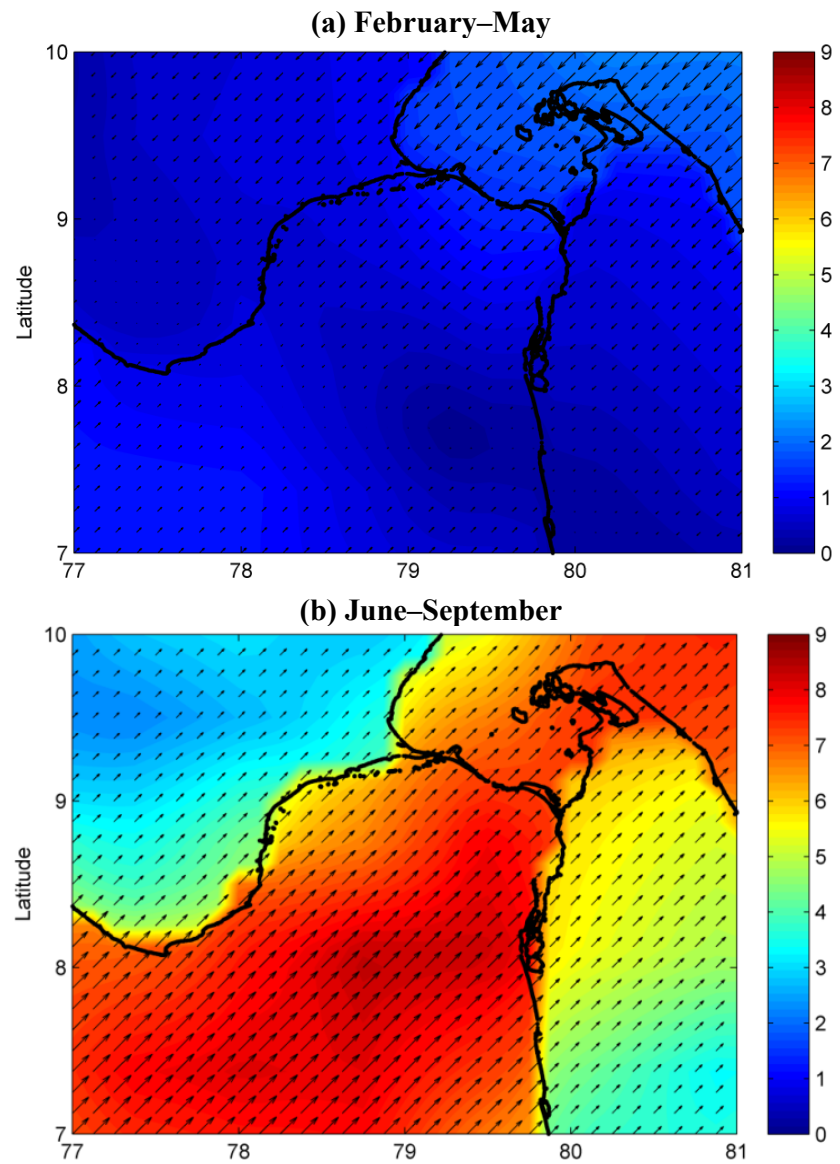

(c) October-January

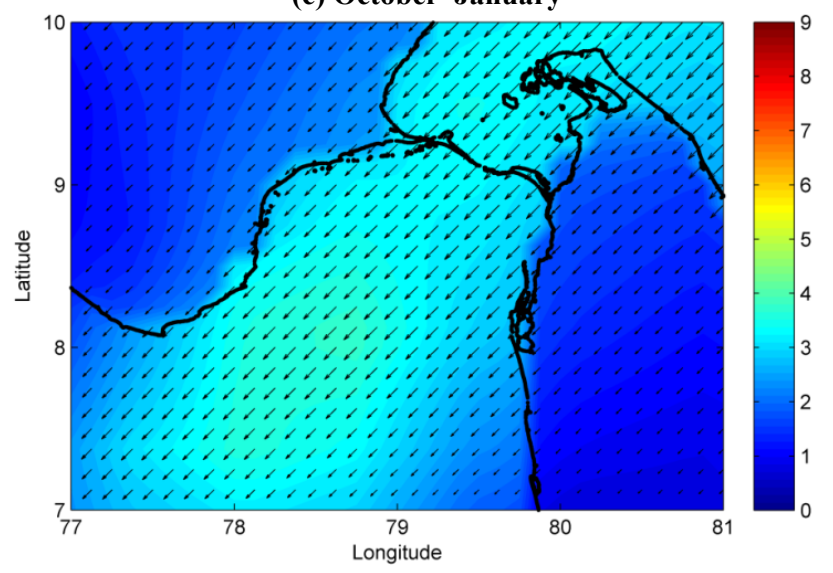

Figure 2. Wind field over the study area in different seasons; (a) pre-monsoon (February-May), (b) southwest monsoon (JuneSeptember) and (c) northeast monsoon (October-January). The wind field is from ERA-Interim reanalysis data and the wind speed is in $\mathrm{ms}^{-1}$.

the measured buoy heave data through a fast Fourier transform of eight series, each consisting of 256 data points. The resolution of the wave spectrum is $0.005 \mathrm{~Hz}$ from 0.025 to $0.1 \mathrm{~Hz}$ and thereafter it is $0.01 \mathrm{up}$ to $0.58 \mathrm{~Hz}$. From the wave spectrum, significant wave height $\left(H_{\mathrm{m} 0}\right)$, mean wave period 


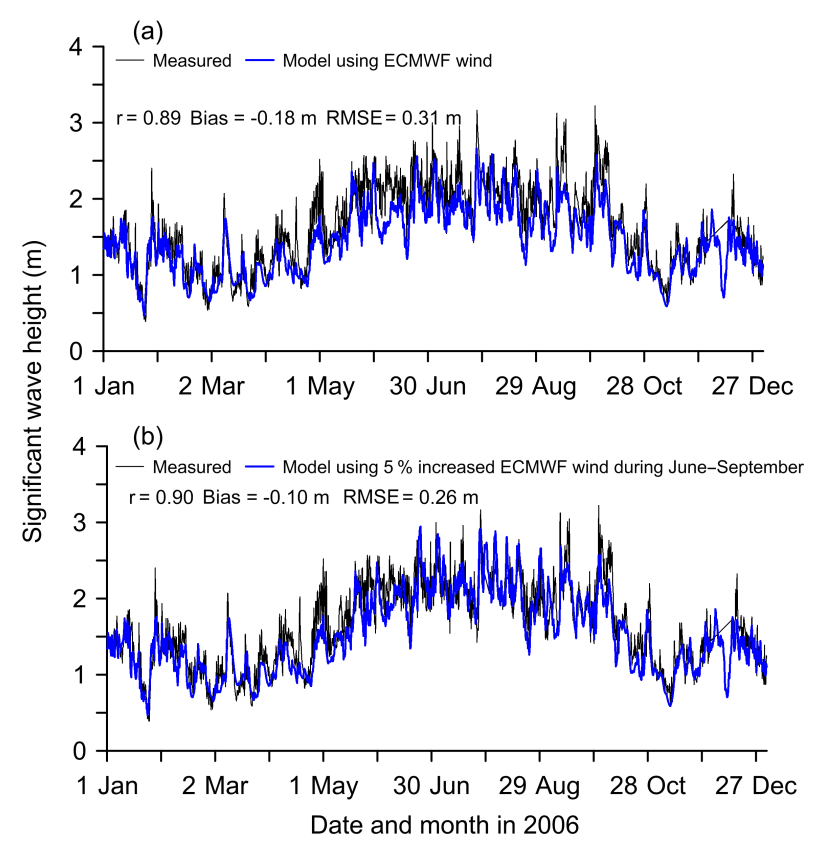

Figure 3. Time history of simulated significant wave height through numerical model forced by (a) ECMWF wind fields and (b) ECMWF wind speed increased by $5 \%$ during June-September and its comparison with field measurements at $8.27^{\circ} \mathrm{N}, 78.56^{\circ} \mathrm{E}$ during January-December 2006.

$\left(T_{\mathrm{m} 02}\right)$ and spectral peak period $\left(T_{\mathrm{p}}\right)$ are estimated for data covering $30 \mathrm{~min}$, and the wave direction is obtained based on circular moments (Kuik et al., 1988). Other parameters estimated are the maximum spectral energy density, spectral peakedness parameter $\left(Q_{\mathrm{p}}\right)(\mathrm{Goda}, 1970)$ and spectral narrowness parameter $(v)$ (Longuet-Higgins, 1984). The directional spectra are based on the maximum entropy method (Lygre and Krogstad, 1986). Measurements reported in this article are in Coordinated Universal Time (UTC) and the local time is $5.5 \mathrm{~h}$ ahead of UTC. The method proposed by Portilla et al. (2009) is used to separate the wind seas and swells from the measured data. The 1-D separation algorithm is on the assumption that the energy at the peak frequency of a swell cannot be higher than the value of a PiersonMoskowitz (PM) spectrum with the same frequency. If the ratio between the peak energy of a wave system and the energy of a PM spectrum at the same frequency is above a threshold value of 1 , the system is considered to represent wind sea; otherwise, it is taken to be a swell. A separation frequency $f_{\mathrm{c}}$ is estimated following Portilla et al. (2009) and the swell and wind-sea parameters are obtained for frequencies ranging from $0.025 \mathrm{~Hz}$ to $f_{\mathrm{c}}$ and from $f_{\mathrm{c}}$ to $0.58 \mathrm{~Hz}$, respectively. The deep-water $\left(8.27^{\circ} \mathrm{N}, 78.56^{\circ} \mathrm{E}\right)$ wave data from 1 January to 31 December 2006 are used for comparison of the model results in the deep water.

\subsection{Model}

The third-generation spectral wave model WAVEWATCH III version 4.18 (Tolman, 1991, 2014) is used in the wave hindcast studies. The source term of the model consists of several parts: a wind-wave interaction, nonlinear wave-wave interactions, a dissipation (whitecapping) and wave-bottom interactions. The treatment of the nonlinear interactions defines a third-generation wave model which is modeled here using the discrete interaction approximation (DIA; Hasselmann et al., 1985). The source term package (ST4) of Ardhuin et al. (2010) is used as the input and dissipation source terms. The JONSWAP parameterization (BT1) is used as the empirical relation for bottom friction (Tolman, 2014). For the southern and large parts of the Indian Ocean domain, the model grid resolution is $0.5^{\circ} \times 0.5^{\circ}\left(20-112^{\circ} \mathrm{E}\right.$ and $70^{\circ} \mathrm{S}-$ $\left.35^{\circ} \mathrm{N}\right)$ and $0.1^{\circ} \times 0.1^{\circ}$ for the north Indian Ocean $\left(65-90^{\circ} \mathrm{E}\right.$ and $5-25^{\circ} \mathrm{N}$ ). The model is forced with ERA-Interim (Dee et al., 2011) surface wind fields at every $6 \mathrm{~h}$ interval with a spatial resolution of $0.5^{\circ}$. The resolution in wave direction is $10^{\circ}$ and the wave frequencies are on a logarithmic scale from 0.04 to $0.5 \mathrm{~Hz}$. The model output for the period of 1 May 2015 to 30 April 2016 at four locations along longitude $78.25^{\circ} \mathrm{E}$ is used to study the variations in the swell percentage when the waves propagate from 7 to $8.5^{\circ} \mathrm{N}$. The model results $\left(H_{\mathrm{m} 0}\right.$, mean wave period and mean wave direction) are also compared with the ECMWF wave data at longitude $78.25^{\circ} \mathrm{E}$ and latitudes 7, 7.5 and $8^{\circ} \mathrm{N}$. Wind-sea and swell percentage from the model output extracted at $8^{\circ} \mathrm{N}$ is used for studying the trend in the $H_{\mathrm{m} 0}$ and the wind-sea and swell percentage for 36 years (1980-2015). The trend is estimated based on the slope of the linear best-fit curve to the annual mean value for 36 years.

\subsection{Error estimates}

The error statistics for significant wave height, mean wave period, mean wave direction from the model against measured and ERA-Interim data were computed based on bias, root mean square error (RMSE), scatter index (SI) and Pearson's linear correlation coefficient $(r)$ as defined below:

$$
\begin{aligned}
& \text { Bias }=\frac{1}{N} \sum_{i=1}^{N}\left(A_{i}-B_{i}\right), \\
& \text { RMSE }=\sqrt{\frac{1}{N} \sum_{i=1}^{N}\left(A_{i}-B_{i}\right)} 2 \\
& \mathrm{SI}=\frac{\mathrm{RMSE}}{\bar{B}}, \\
& r=\frac{\sum_{i=1}^{N}\left|\left(A_{i}-\bar{A}\right)\left(B_{i}-\bar{B}\right)\right|}{\sqrt{\sum_{i=1}^{N}\left(A_{i}-\bar{A}\right)^{2}} \sqrt{\sum_{i=1}^{N}\left(B_{i}-\bar{B}\right)^{2}}},
\end{aligned}
$$



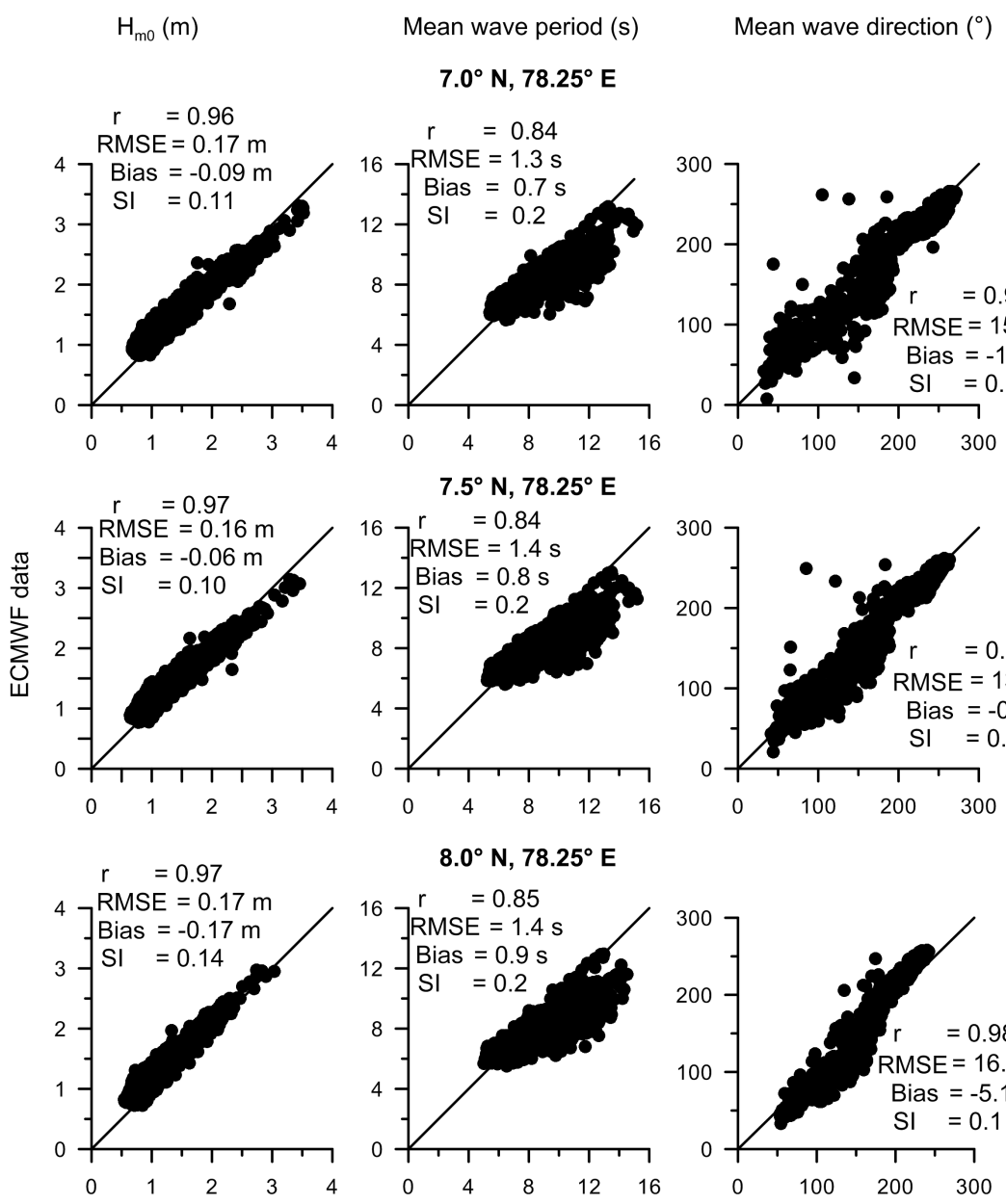

$7.5^{\circ} \mathrm{N}, 78.25^{\circ} \mathrm{E}$
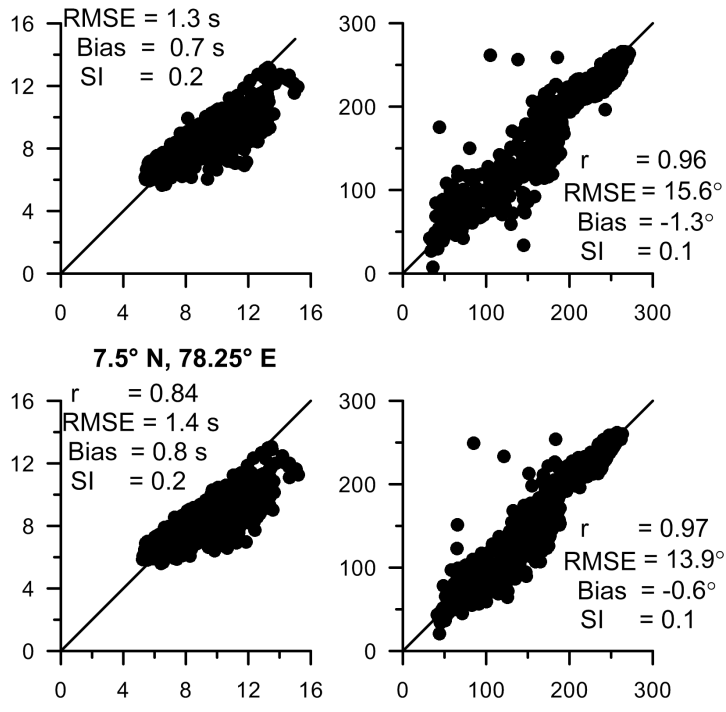

$8.0^{\circ} \mathrm{N}, 78.25^{\circ} \mathrm{E}$
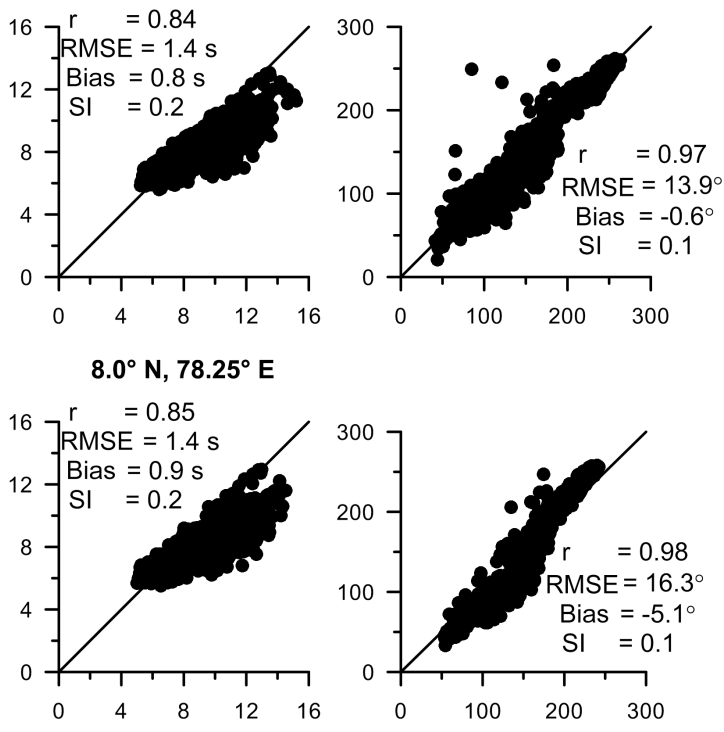

Values from numerical model

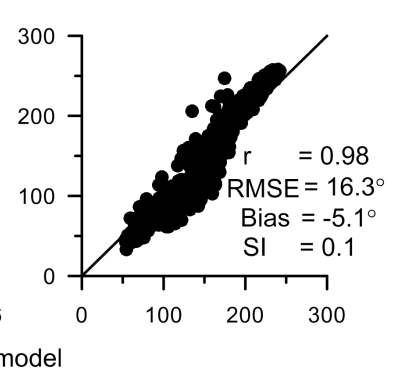

Figure 4. Correlation between model data and ECMWF ERA-Interim data of significant wave height, mean wave period and mean wave direction at different locations.

where $A_{i}$ and $B_{i}$ represent the parameter based on numerical model and measured data, $N$ is the number of data points and the over bar represents the mean value.

\subsection{Comparison of model output with measured data}

The $H_{\mathrm{m} 0}$ is extracted for the point $8.27^{\circ} \mathrm{N}, 78.56^{\circ} \mathrm{E}$ from the model and compared with the measured buoy data (Fig. 3). The comparison between model and measured $H_{\mathrm{m} 0}$ for the year 2006 shows bias, RMSE, SI and $r$ values of $-0.18 \mathrm{~m}$, $0.31 \mathrm{~m}, 0.19$ and 0.89 , respectively. The wave heights are underpredicted by the model and the underprediction is larger during the monsoon period. A $5 \%$ increase in the forcing wind field during monsoon period improved the comparison statistics of bias, RMSE, SI and $r$ values to $-0.10 \mathrm{~m}, 0.26 \mathrm{~m}$, 0.16 and 0.90 , respectively

We compared the model $H_{\mathrm{m} 0}$, mean wave period and mean wave direction with ERA-Interim wave data for three deepwater points having the same longitude of $78.25^{\circ} \mathrm{E}$ and dif- ferent latitudes of 7.0, 7.5 and $8.0^{\circ} \mathrm{N}$ (Fig. 4). It is found that the model $H_{\mathrm{m} 0}$ is in comparatively good agreement with ERA-Interim $H_{\mathrm{m} 0}$ : bias ranging from -0.17 to $-0.06 \mathrm{~m}$ shows the underestimation by the model, RMSE has a range of 0.16 to $0.17 \mathrm{~m}$, SI ranges from 0.10 to 0.14 and correlation coefficient is around 0.97 . The statistical parameters (bias, RMSE, SI and $r$ ) for the wave period have ranges of 0.84 to $0.85 \mathrm{~s}, 1.3$ to $1.4 \mathrm{~s}, 0.2,0.84$ to 0.85 . Similarly, ranges for bias, RMSE and SI for mean wave direction are -5.1 to $-0.6^{\circ}, 13.9$ to $16.3^{\circ}$ and 0.1 , respectively.

\section{Result and discussions}

\subsection{Wave parameters statistics}

Based on the maxima, mean value and standard deviation, the statistical analysis of the main wave characteristics is obtained. The directional wave parameter presented here is the 

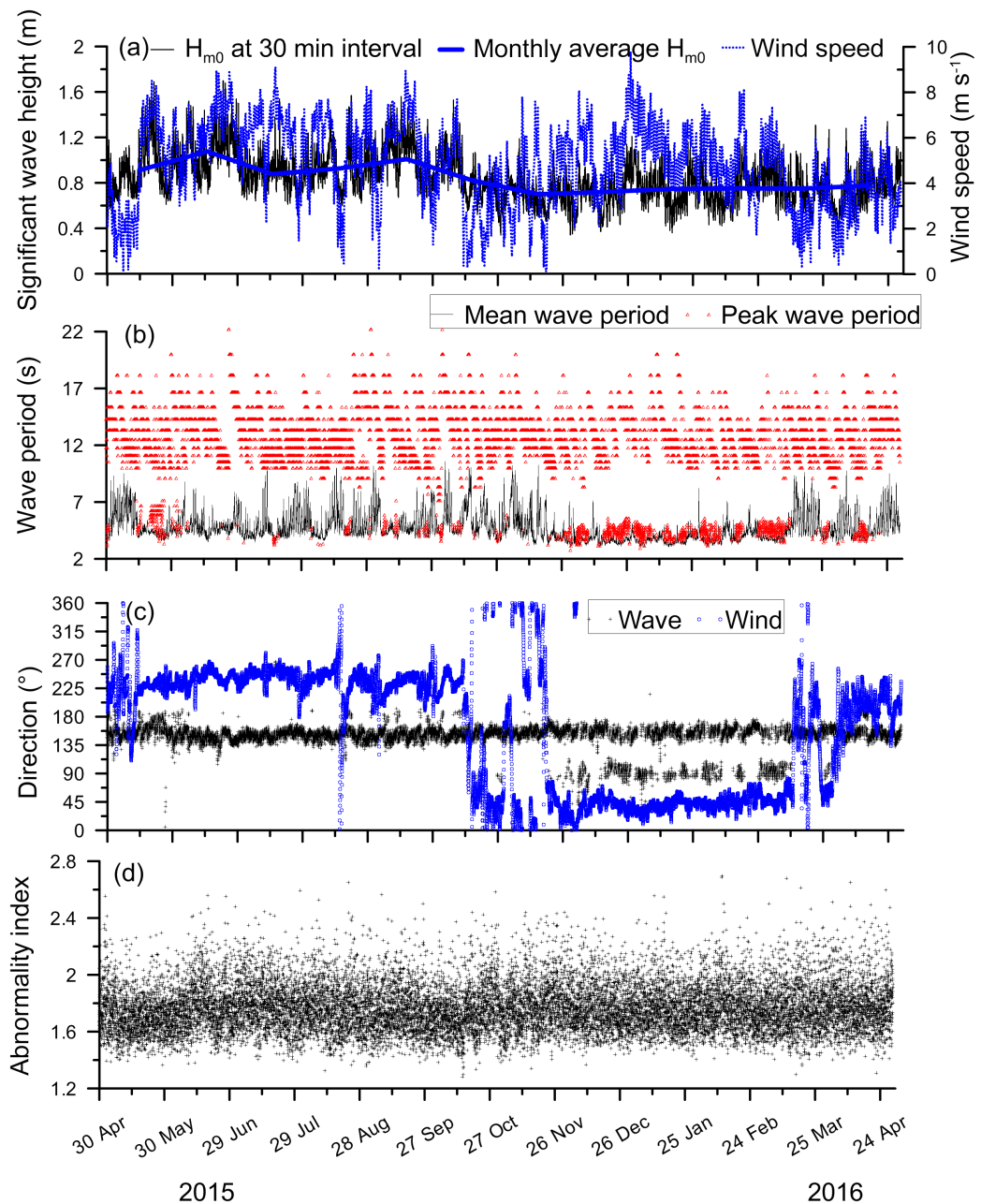

Figure 5. Time series plots of (a) significant wave height and wind speed, (b) mean wave period for data covering 30 min and peak wave period, (c) direction of wind and wave and (d) abnormality index. The monthly average significant wave height values are also shown.

Table 2. Statistics of each month: mean value, standard deviation, maximum and minimum of significant wave height along with swell and wind-sea percentage in the measured data.

\begin{tabular}{lrrrrrrr}
\hline Month & $\begin{array}{r}\text { Mean } \\
(\mathrm{m})\end{array}$ & $\begin{array}{r}\text { Standard } \\
\text { deviation }(\mathrm{m})\end{array}$ & $\begin{array}{r}\text { Maximum } \\
(\mathrm{m})\end{array}$ & $\begin{array}{r}\text { Minimum } \\
(\mathrm{m})\end{array}$ & $\begin{array}{r}\text { No. of } \\
\text { data }\end{array}$ & $\begin{array}{r}\text { Swell } \\
(\%)\end{array}$ & $\begin{array}{r}\text { Wind sea } \\
(\%)\end{array}$ \\
\hline May 2015 & 0.91 & 0.22 & 1.69 & 0.46 & 1488 & 54.3 & 45.7 \\
June 2015 & 1.08 & 0.19 & 1.70 & 0.70 & 1439 & 58.0 & 42.0 \\
July 2015 & 0.88 & 0.12 & 1.54 & 0.61 & 1488 & 64.5 & 35.5 \\
August 2015 & 0.93 & 0.17 & 1.57 & 0.60 & 1488 & 63.9 & 36.1 \\
September 2015 & 1.01 & 0.19 & 1.56 & 0.55 & 1438 & 58.8 & 41.2 \\
October 2015 & 0.82 & 0.20 & 1.53 & 0.34 & 1488 & 63.3 & 36.7 \\
November 2015 & 0.70 & 0.13 & 1.19 & 0.34 & 1439 & 59.8 & 40.2 \\
December 2015 & 0.72 & 0.17 & 1.21 & 0.35 & 1488 & 30.7 & 69.3 \\
January 2016 & 0.75 & 0.15 & 1.27 & 0.36 & 1484 & 28.9 & 71.1 \\
February 2016 & 0.75 & 0.16 & 1.15 & 0.42 & 1389 & 38.0 & 62.0 \\
March 2016 & 0.75 & 0.16 & 1.31 & 0.43 & 1488 & 53.6 & 46.4 \\
April 2016 & 0.78 & 0.17 & 1.34 & 0.37 & 1440 & 60.1 & 39.9 \\
\hline Annual average & 0.84 & 0.21 & $1.70 *$ & $0.34 *$ & 1463 & 52.8 & 47.2 \\
\hline
\end{tabular}

*Extremes. 
Table 3. Average wave parameters and amount of data in different spectral peak frequencies.

\begin{tabular}{lrrrr}
\hline $\begin{array}{l}\text { Peak frequency } \\
\left(f_{\mathrm{p}}\right) \text { range }(\mathrm{Hz})\end{array}$ & $\begin{array}{r}\text { Number of } \\
\text { data and \% }\end{array}$ & $\begin{array}{r}H_{\mathrm{m} 0}(\mathrm{~m}) \\
\hline 0.04<f_{\mathrm{p}} \leq 0.05\end{array}$ & $\begin{array}{r}T_{\mathrm{m} 02} \\
(\mathrm{~s})\end{array}$ & $\begin{array}{r}\text { Peak wave } \\
\text { period }(\mathrm{s})\end{array}$ \\
$0.05<f_{\mathrm{p}} \leq 0.06$ & $139(0.79)$ & 0.91 & 4.98 & 20.14 \\
$0.06<f_{\mathrm{p}} \leq 0.07$ & $3838(21.86)$ & 0.91 & 5.17 & 17.13 \\
$0.07<f_{\mathrm{p}} \leq 0.08$ & $4429(25.23)$ & 0.80 & 4.97 & 14.71 \\
$0.08<f_{\mathrm{p}} \leq 0.10$ & $4921(28.03)$ & 0.82 & 4.71 & 11.06 \\
$0.10<f_{\mathrm{p}} \leq 0.15$ & $368(2.10)$ & 0.80 & 4.50 & 8.69 \\
$0.15<f_{\mathrm{p}} \leq 0.20$ & $477(2.72)$ & 1.05 & 4.03 & 5.30 \\
$0.20<f_{\mathrm{p}} \leq 0.30$ & $1779(10.13)$ & 0.86 & 3.65 & 4.32 \\
$0.30<f_{\mathrm{p}} \leq 0.50$ & $33(0.19)$ & 0.73 & 3.33 & 3.23 \\
\hline
\end{tabular}

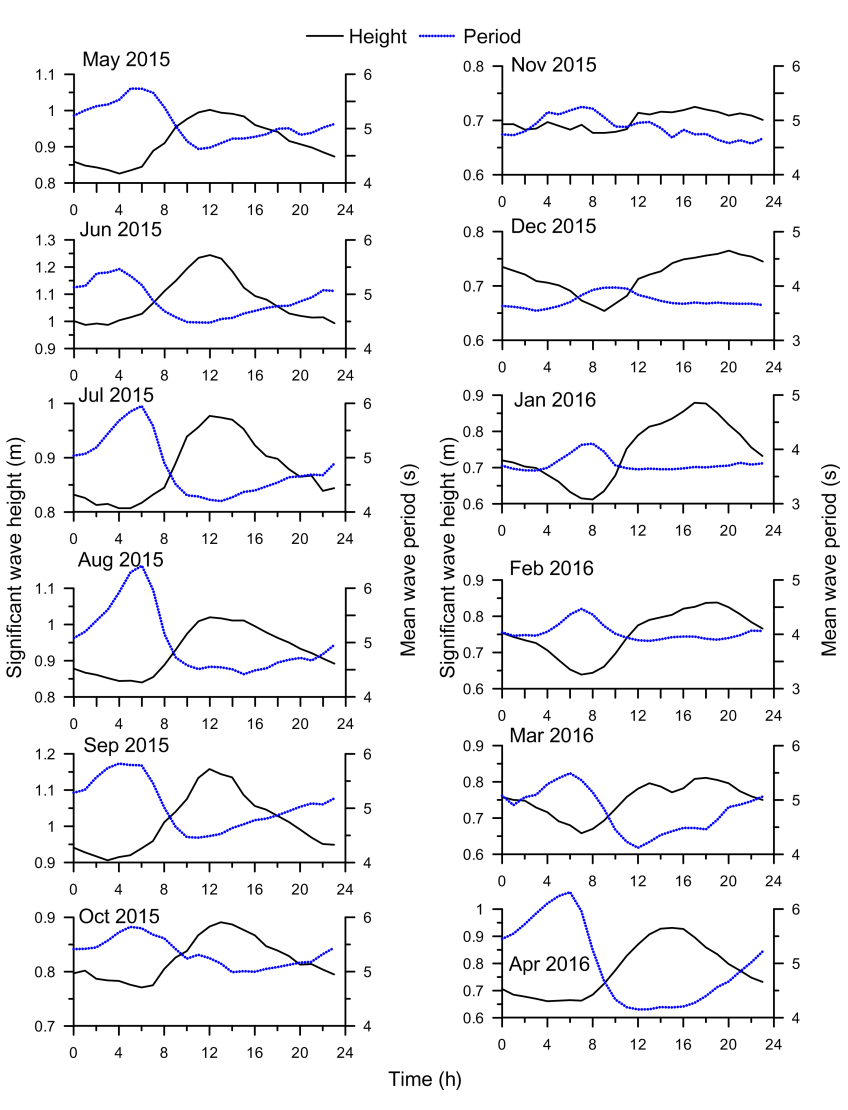

Figure 7. Variation of hourly averaged significant wave height and mean wave period in different months.

is partially restricted and high waves are not observed compared to those in the open-sea conditions along the western Bay of Bengal and the eastern Arabian Sea. Even though the study location is in a gulf and high waves are not observed, the annual mean $H_{\mathrm{m} 0}$ observed at the study region $(0.84 \mathrm{~m})$ is comparable to the values $(0.7$ to $1.1 \mathrm{~m})$ reported for other locations in the western Bay of Bengal and eastern Arabian Sea (Gowthaman et al., 2013; Sanil Kumar et al., 2013).

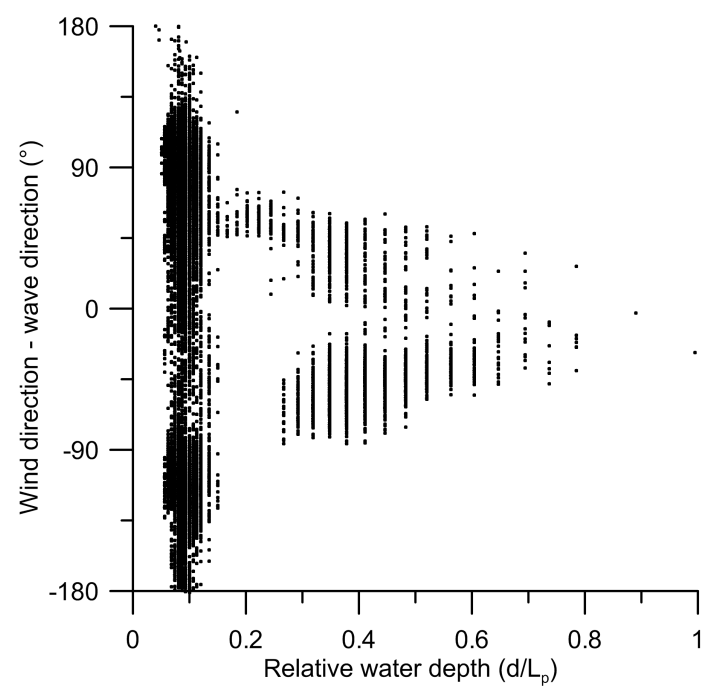

Figure 8. Variation of difference in wind and wave direction with relative water depth.

On 8 November 2015, a depression was formed in the Bay of Bengal and later it was upgraded to a deep depression and crossed the coast of Tamil Nadu near Puducherry with peak wind speeds of $15.3 \mathrm{~m} \mathrm{~s}^{-1}\left(55 \mathrm{~km} \mathrm{~h}^{-1}\right)$ and a minimum central pressure of $991 \mathrm{hPa}$ (IMD, 2015). Even though the wave measurement location is only $370 \mathrm{~km}$ from the track of the depression, the influence of this deep depression is not observed in the measured wave data. This shows that the waves in GoM are not influenced by the storms north of Palk Bay. The gradual increase in wave height seen in May and June is associated with the summer monsoon (Fig. 5). The locally generated waves (wind sea) and the swells are separated to identify different wave components at the study location. Swell $H_{\mathrm{m} 0}$ up to $1.23 \mathrm{~m}$ is recorded with a mean value of $0.58 \mathrm{~m}$, whereas the mean wind-sea $H_{\mathrm{m} 0}$ is $0.56 \mathrm{~m}$ with a maximum value of $1.62 \mathrm{~m}$. The high wind-sea $H_{\mathrm{m} 0}$ is observed in May with negligible swell $(8-10 \%)$ on that occasion; the swell was not always negligible in May.

A wide range ( 3 to $22 \mathrm{~s}$ ) is observed in the peak wave period with a mean value of $12 \mathrm{~s}$, indicating that the wave regime of the study area consists of short- to long-period waves. Even though wind seas and swells are present in the study area, the variation over an annual cycle in mean wave period is 3 to $11 \mathrm{~s}$ with the mean value of $4.7 \mathrm{~s}$. For all months, the mean wave periods are still short relative to other areas in the western part of the Bay of Bengal and the eastern part of the Arabian Sea (5 to $6.5 \mathrm{~s}$ ). Distribution of mean wave direction for the three seasons is similar for the swells throughout the year except in the southwest monsoon months. However, for the wind seas, a large variation in wave direction is observed from October to May. Shortperiod waves $\left(T_{\mathrm{p}}<6 \mathrm{~s}\right)$ approach from east, northeast, southeast and south except in the southwest monsoon months. In the southwest monsoon period, the short-period waves ap- 


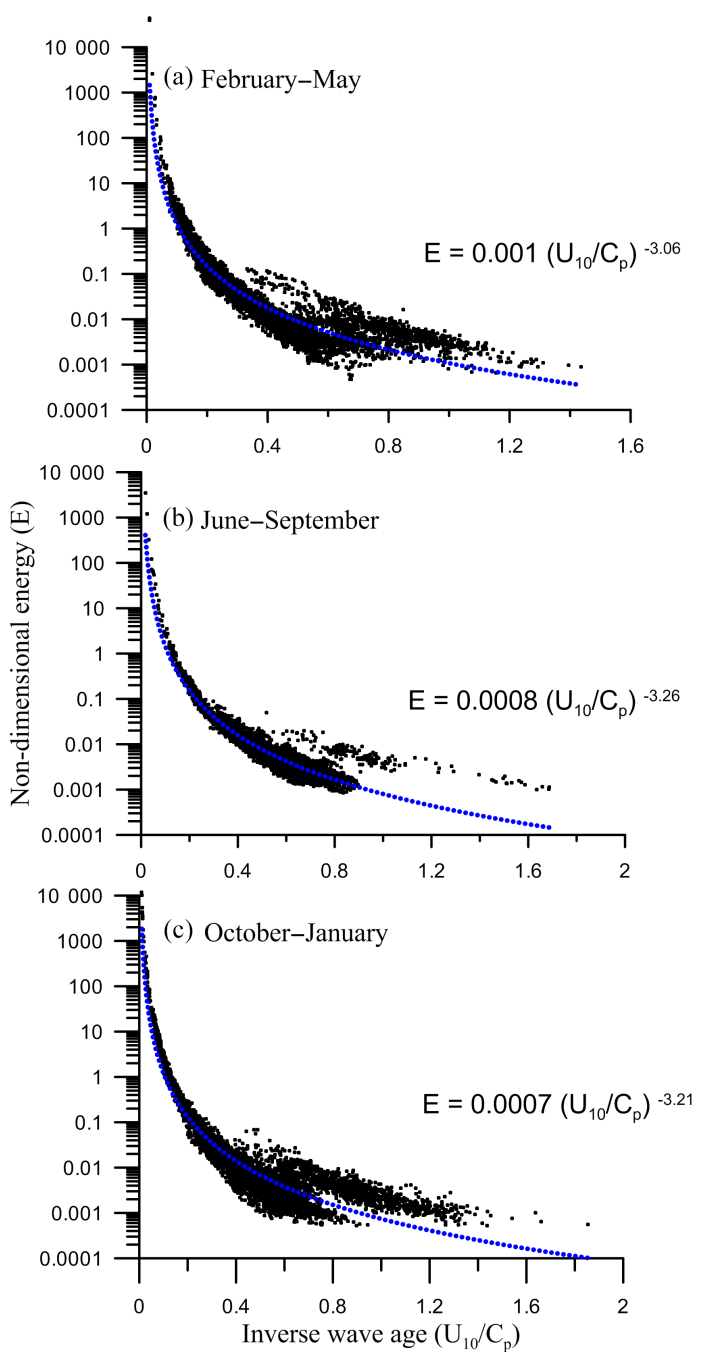

Figure 9. Variation of non-dimensional energy with inverse wave age in different periods: (a) February-May, (b) June-September and (c) October-January.

proach from southeast and south. Waves with a period of more than $8 \mathrm{~s}$ are mainly from south and southeast (Fig. 6). Over an annual cycle, $31.6 \%$ of the time, long-period waves $\left(T_{\mathrm{p}}>14 \mathrm{~s}\right)$ are also observed (Table 3 ) and these swell waves are produced from storms in the Southern Ocean and reach the Indian coast within 5 to 6 days (Amrutha et al., 2017).

A total of $53 \%$ of the surface height variance at the study area over the annual cycle is a result of the south and southeast swells and the balance is the east and southeast wind seas (Table 2). The wave field at the study region shows the dominance of swells over the wind seas, which is in agreement with that reported for the areas around the Indian coast (Sanil Kumar et al., 2003, 2012, 2014; Glejin et al., 2013). However, in the southwest monsoon period, the seasonal average swell contribution is $61 \%$, whereas it varies from 70 to $79 \%$ for locations around India (Sanil Kumar et al., 2014). Over the western GoM during most of the time, the wave climate is characterized by sea-land breeze structure and is feeble during November and December (Fig. 7). The waves in the western GoM are under the control of wind seas generated by sea breeze in a diurnal pattern, with the maximum during the late evening and the minimum during the early morning, and are similar to those reported over the southwestern Bay of Bengal (Glejin et al., 2013).

Wave length linked with the mean wave period ranged from 14 to $107 \mathrm{~m}$ and the ratio of water depth and wave length (varied from 0.11 to 0.85 ) is more than 0.5 during $27 \%$ of the time, indicating that for $27 \%$ of the time the measured waves are in the deep-water condition (USACE, 1984). On separating the waves into wind seas and swells, it is observed that $97 \%$ of the wind seas are in the deep-water condition, whereas $98 \%$ of the time the swells satisfy the transitional water condition (ratio of water depth and wave length between 0.05 and 0.5 ). The water depth to wave length ratio shows that the wave height and the wave direction presented in this article will be influenced by the sea bed. Wind and wave directions corresponding to spectral peak differ by 20 to $120^{\circ}$ during most of the time since the measurements are made close $(\sim 12 \mathrm{~km})$ to the coast and the wave direction will be mostly aligned to the depth contour due to refraction, whereas such changes in wind direction are not expected (Fig. 5). When the difference between the wind and wave direction is more than $45^{\circ}$, the relative water depth based on spectral peak period $\left(d / L_{p}\right)$ shows that the wave regime is in intermediate and shallow water (Fig. 8). During the deep-water regime, the difference between the wind and wave direction is less than $45^{\circ}$.

The wind is predominantly southwesterly from March to September and from northeast during October to February, and the average wind speed is $4.8 \mathrm{~m} \mathrm{~s}^{-1}$ (Fig. 5a and c). The nature of sea state can be recognized based on the wave age $\left(C / U_{10}\right)$ and the steepness of wave $\left(H_{\mathrm{m} 0} / L\right)$, where $C$ is the phase speed corresponding to the mean wave period. Based on wave steepness, Thompson et al. (1984) grouped ocean waves as locally generated waves if the steepness values were greater than 0.025 . The wave measurements in this study show that $61 \%$ of the time wave steepness is greater than 0.025 . An old sea is defined when wave age is greater than 25 , and when the wave age is less than 10 , it is a young sea. For the present data, wave age is less than 10 during $98 \%$ of the time, indicating young seas with the presence of young swells. Donelan et al. (1993) identified that the value of the spectrum at full development corresponds to $U_{10} / C_{\mathrm{p}}=0.83$, where the spectral components above this value are classified as wind seas and those below as swells, and $C_{\mathrm{p}}$ is the phase speed of the waves corresponding to the spectral peak. For the study location, the inverse wave age is more than 0.83 for $7 \%$ of the time (Fig. 9). Inverse wave age values are biased towards lower values with peaks in the range of 0.4-0.8, indicating a young-swell-driven wave regime along the study area. 
Table 4. Percentage of single-peaked and multi-peaked wave spectra in different months along with classification as wind sea, swell or mixed, based on the spectral peak period.

\begin{tabular}{|c|c|c|c|c|c|c|c|c|}
\hline \multirow[b]{2}{*}{ Month } & \multicolumn{4}{|c|}{ Single peak $(\%)$} & \multicolumn{4}{|c|}{ Multi-peak (\%) } \\
\hline & Total & $\begin{array}{r}\text { Wind sea } \\
\left(T_{\mathrm{p}}<6\right)\end{array}$ & $\begin{array}{r}\text { Swell } \\
\left(T_{\mathrm{p}}>8\right)\end{array}$ & $\begin{array}{r}\text { Mixed } \\
\left(6<T_{\mathrm{p}}<8\right)\end{array}$ & Total & $\begin{array}{r}\text { Wind-sea } \\
\text { dominated } \\
\left(T_{\mathrm{p}}<6\right)\end{array}$ & $\begin{array}{r}\text { Swell } \\
\text { dominated } \\
\left(T_{\mathrm{p}}>8\right)\end{array}$ & $\begin{array}{r}\text { Mixed } \\
\left(6<T_{\mathrm{p}}<8\right)\end{array}$ \\
\hline May & 40.2 & 0.8 & 39.4 & 0 & 59.8 & 9.7 & 45.6 & 4.6 \\
\hline June & 55.8 & 0.1 & 55.7 & 0 & 44.2 & 1.7 & 42.1 & 0.4 \\
\hline July & 57.8 & 0.0 & 57.8 & 0 & 42.2 & 1.1 & 41.1 & 0.0 \\
\hline August & 48.3 & 0.0 & 48.3 & 0 & 51.7 & 3.3 & 48.4 & 0.0 \\
\hline September & 51.3 & 0.1 & 51.2 & 0 & 48.7 & 5.6 & 43.0 & 0.2 \\
\hline October & 48.0 & 0.1 & 47.9 & 0 & 52.0 & 4.2 & 46.9 & 0.9 \\
\hline November & 47.0 & 0.0 & 47.0 & 0 & 53.0 & 3.3 & 49.8 & 0.0 \\
\hline December & 15.0 & 0.5 & 14.4 & 0 & 85.0 & 34.2 & 50.8 & 0.0 \\
\hline January & 9.5 & 0.5 & 9.0 & 0 & 90.5 & 31.4 & 59.1 & 0.0 \\
\hline February & 25.1 & 0.3 & 24.8 & 0 & 74.9 & 27.5 & 47.4 & 0.0 \\
\hline March & 43.3 & 0.0 & 43.3 & 0 & 56.7 & 21.8 & 34.8 & 0.0 \\
\hline April & 56.5 & 0.1 & 56.5 & 0 & 43.5 & 8.5 & 35.0 & 0.0 \\
\hline $\begin{array}{l}\text { Annual } \\
\text { average }\end{array}$ & 41.5 & 0.2 & 41.3 & 0.0 & 58.5 & 12.7 & 45.3 & 0.5 \\
\hline
\end{tabular}

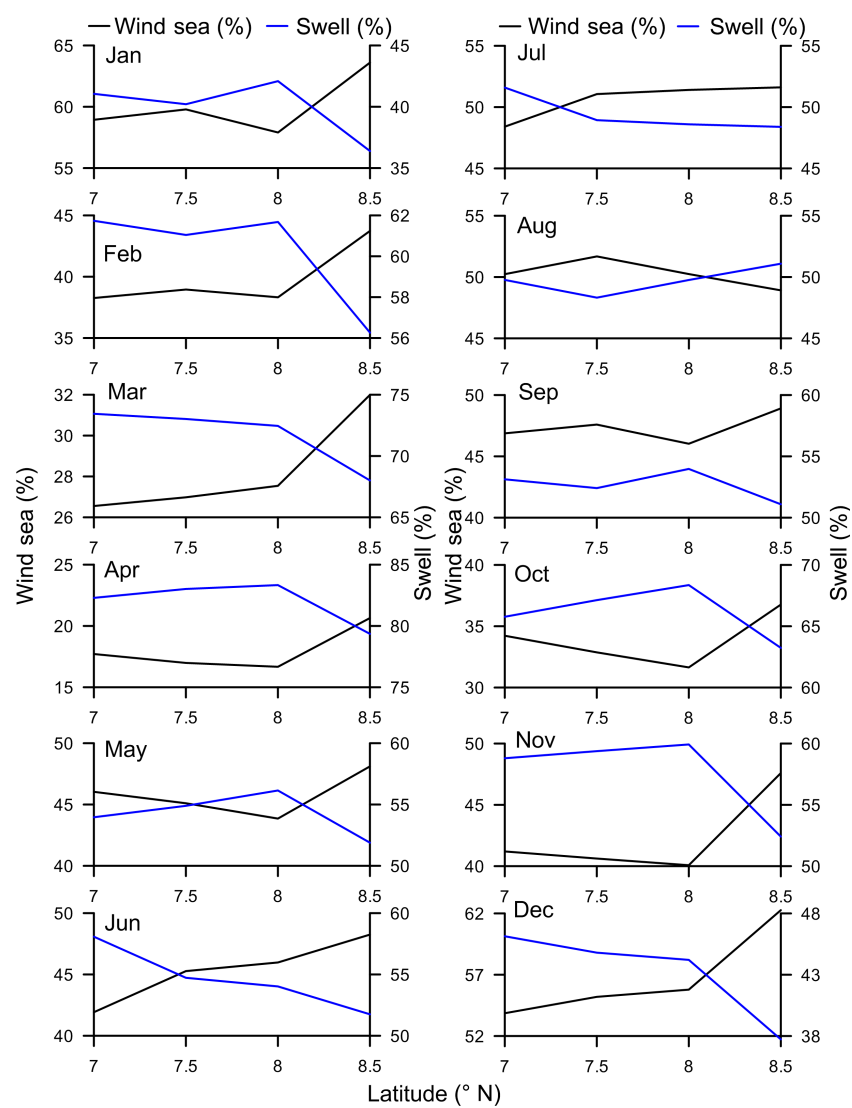

Figure 10. Swell and wind-sea percentage at $7,7.5,8$ and $8.5^{\circ} \mathrm{N}$ latitudes in different months based on wave model results.

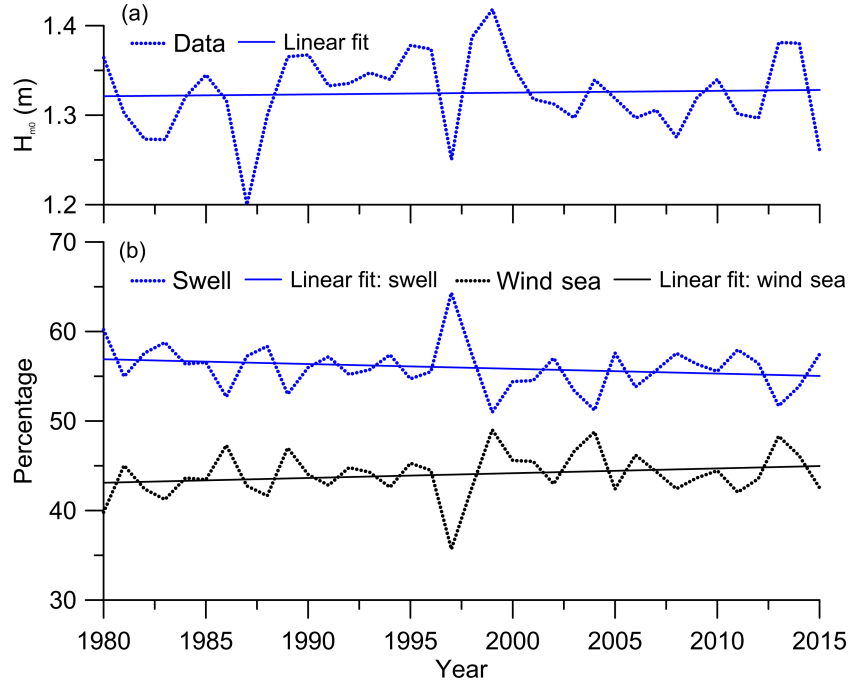

Figure 11. Variation in (a) significant wave height and (b) swell and wind-sea percentage at $8^{\circ} \mathrm{N}, 78.29^{\circ} \mathrm{E}$ during 1980-2015. Linear trend is also presented.

We have examined the variations in swells and wind seas of the surface height variance as the wave propagates from deep water to the shallow waters based on wave model results. The monthly average swell and wind-sea percentage along a longitude transect of $78.25^{\circ} \mathrm{E}$ at $7.0^{\circ}, 7.5,8.0$ and $8.5^{\circ} \mathrm{N}$ latitudes is presented in Fig. 10. The study shows that, in all months, the percentage of swells decreased as the waves moved from open ocean to bay $\left(7.0\right.$ to $8.5^{\circ} \mathrm{N}$ latitude) with an average decrease of $\sim 5 \%$ in the swells, except 

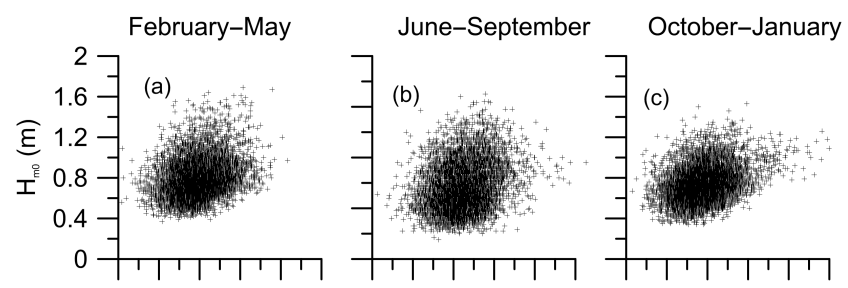

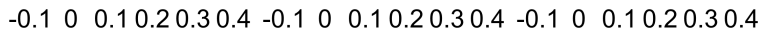
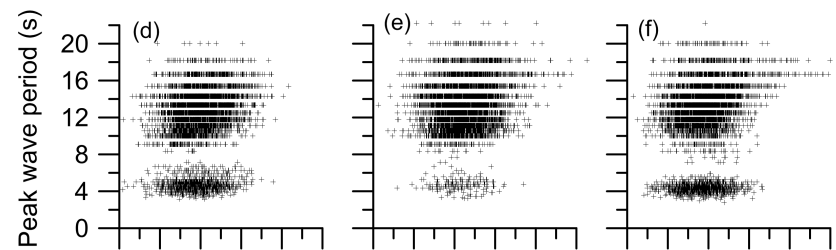

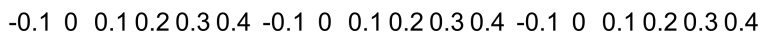
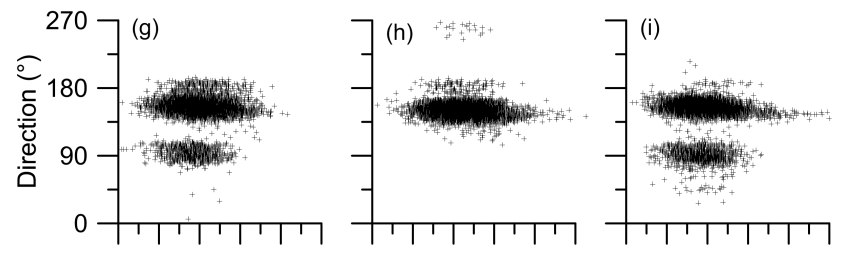

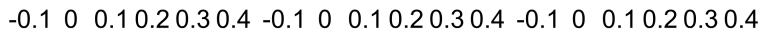
Skewness

Figure 12. Variation of skewness with significant wave height, mean wave period and mean wave direction in different seasons.

in August. The linear trend of the wind-sea and swell percentage at $8.0^{\circ} \mathrm{N}, 78.25^{\circ} \mathrm{E}$ during $1980-2015$ shows that the trend is slightly positive $(0.05 \%)$ for wind seas and negative $(0.05 \%)$ for the swells (Fig. 11b). The $H_{\mathrm{m} 0}$ shows a negligible upward trend $\left(2 \mathrm{~cm} \mathrm{yr}^{-1}\right)$ during 1980-2015 (Fig. 11a). Even though the study area is in a gulf region, since its opening is exactly toward the southwest, the upward trend in $H_{\mathrm{m} 0}$ observed is due to the increase in wave heights in the Southern Ocean (Hemer et al., 2010). Young et al. (2011) indicate a weak increase (0-0.25\% of annual mean value) of $H_{\mathrm{m} 0}$ in the north Indian Ocean based on the 23-year period (19852008) of satellite altimeter measurements.

Nonlinearity in the surface elevations is reflected in sharpening of the wave crests and flattening of the wave troughs, and these effects are reflected in the skewness of the sea surface elevation (Toffoli, 2006). A positive skewness value indicates that the wave crests are bigger than the troughs, and zero skewness indicates linear sea states (Anjali Nair and Sanil Kumar, 2017). Figure 12 shows the variation of skewness with significant wave height, mean wave period and mean wave direction. The waves from the east are mainly the wind seas and gave low skewness values. The high skewness values are for long-period swells $\left(T_{\mathrm{p}}>16 \mathrm{~s}\right)$ superimposed on the wind seas. The increase in nonlinearity with the increase in the $H_{\mathrm{m} 0}$ is not predominant at this location (Fig. 12a-c). The abnormality index $\left(H_{\max } / H_{\mathrm{m} 0}\right)$ more than 2 is observed during $8.5 \%$ of the time, but it is only $1.5 \%$ for waves with $H_{\mathrm{m} 0}$ more than $1 \mathrm{~m}$ (Fig. 5d).
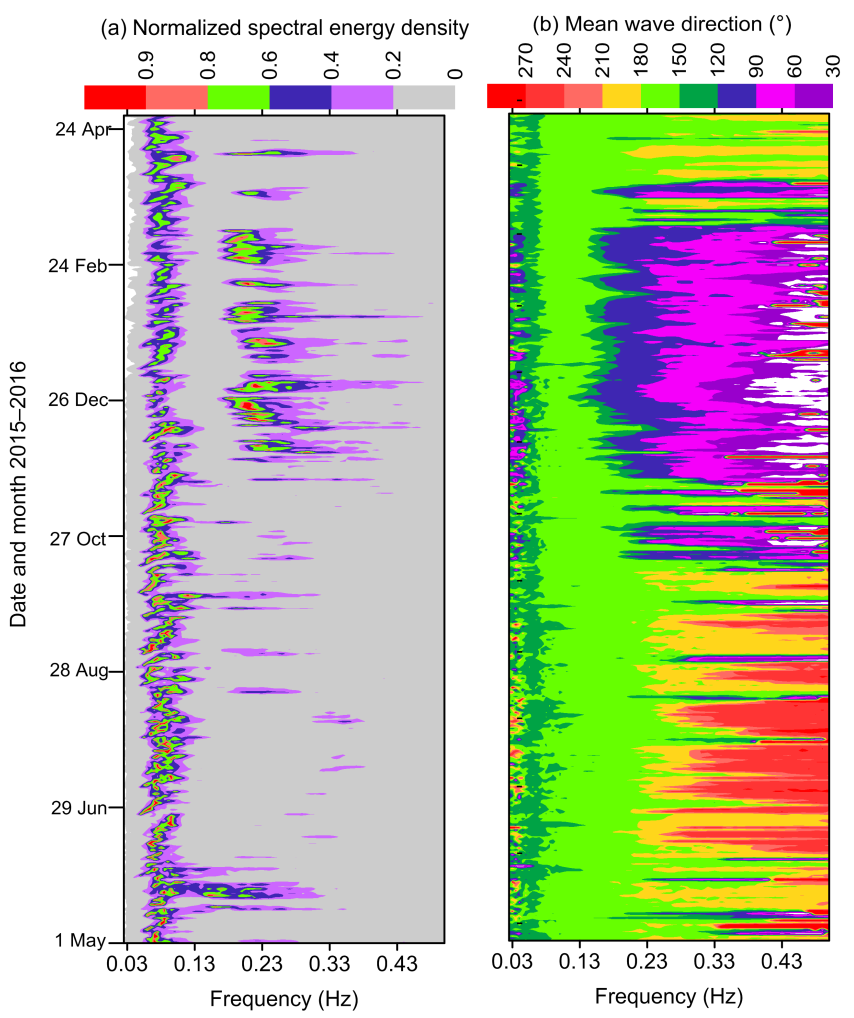

Figure 13. Contour plots of (a) normalized spectral energy density and (b) mean wave direction from 1 May 2015 to 30 April 2016.

\subsection{Wave spectra}

In order to have a better understanding of the wave systems in the study area, we show the characterization of waves through the analysis of each individual spectrum. The wave spectra are generally classified as exhibiting either one or two peaks (Henrique et al., 2015). The dominance of windsea or swell systems varied for both cases and are presented in this section. Measured data consist of single-peaked wind sea, single-peaked swell and wind-sea-dominated or swelldominated multi-peaked spectra (Table 4). A majority of the data recorded are multi-peaked spectra $(58.5 \%$ of the time) and the multi-peaked spectra are swell dominated $45.3 \%$ of time and wind sea dominated $12.7 \%$ of the time. The peak frequency $\left(f_{\mathrm{p}}\right)$ is shown to be unstable when swell and windsea peak energies are similar. The single-peak spectra are mainly swell dominated. Gowthaman et al. (2013) observed that in the northern GoM, swells are predominant in GoM during the non-monsoon period (January-April), and during the rest of the year wind seas dominate. The multi-peaked spectra observed in the present study area are slightly higher than those (37 to 54\%) reported along the eastern Arabian Sea (Sanil Kumar et al., 2014).

The energy distribution of waves over a range of frequencies with time is studied by plotting the normalized wave spectral energy density in the time-frequency frame. Each 

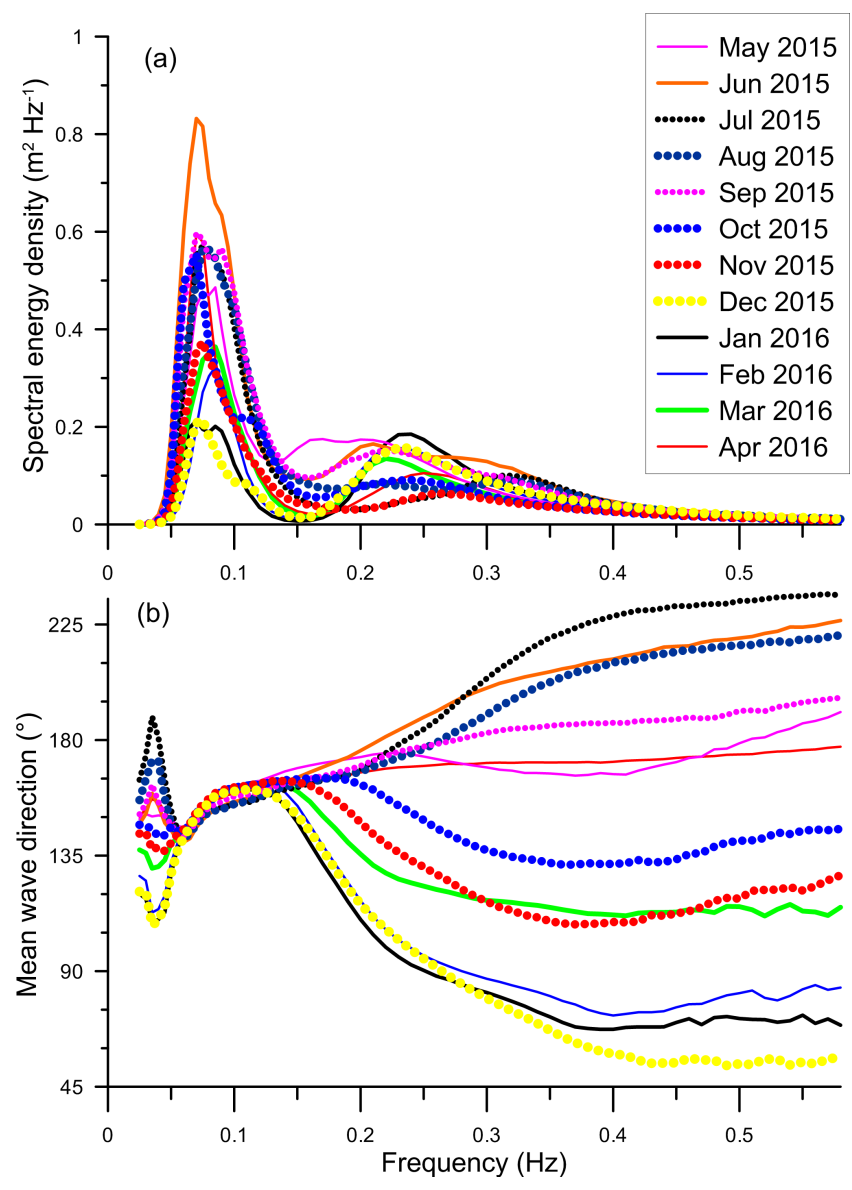

Figure 14. Monthly average wave spectrum (a) and mean wave direction (b) from May 2015 to April 2016.

wave spectrum is normalized by the maximum wave spectral energy density of the respective spectrum. Normalized spectral energy density plots in the time-frequency field indicate the predominance of spectral energy in frequency bands $0.06-0.09 \mathrm{~Hz}$ (corresponding to swells) during most of the time except from November to March during which the energy is $0.18-0.24 \mathrm{~Hz}$ (corresponding to wind seas; Fig. 13). The monthly average wave spectrum shows that the wave spectrum is swell dominated in all months except December and January during which the wind seas dominate (Fig. 14). The peak of the swell part of the monthly averaged wave spectrum varied from 0.07 to $0.08 \mathrm{~Hz}$. Gowthaman et al. (2013) observed that dominance of swells is at its maximum (98\%) during March and dominance of wind seas is at its maximum (94\%) during October in the northern GoM.

Waves of different frequency have different directions. Long-period swells $\left(T_{\mathrm{p}}>14 \mathrm{~s}\right)$ and the intermediate-period waves $\left(14>T_{\mathrm{p}}>6 \mathrm{~s}\right)$ vary from 150 to $180^{\circ}$, whereas the wind-sea direction varies from southwest to northeast (Fig. 13). Waves with the period less than $4 \mathrm{~s}$ come from the northeast and east during November-March and from south to southwest during the remaining period (Fig. 14b).

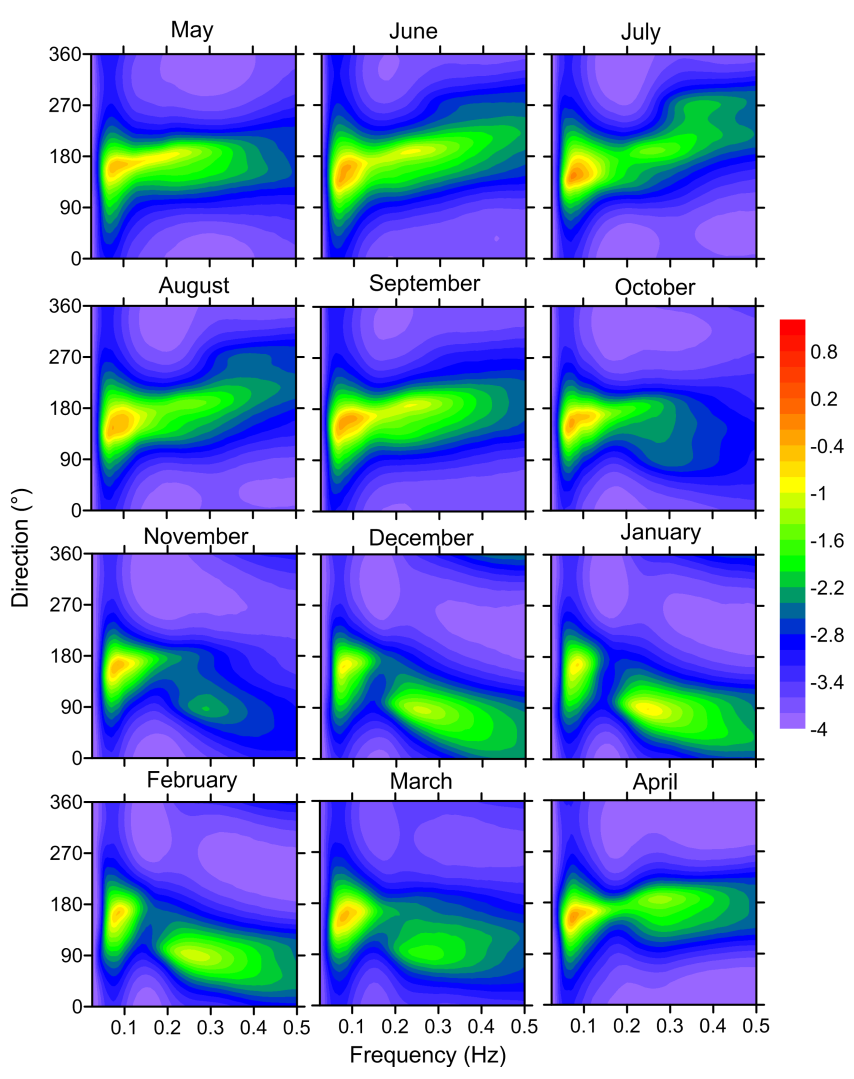

Figure 15. Monthly average directional wave spectrum during different months. The color bar is for spectral energy $\left(\mathrm{m}^{2} \mathrm{deg}^{-1} \mathrm{~Hz}^{-1}\right)$. The spectral energy is shown in logarithmic scale (base 10).

The monthly average wave spectrum has a similar direction for the region from 0.06 to $0.13 \mathrm{~Hz}$ in all months, whereas the average monthly direction varies significantly for regions beyond this frequency range (Fig. 14b). For example, waves with the period less than $3 \mathrm{~s}$ come from the northeast during December-February, southwest during June-August and southeast during the remaining period. The monthly mean directional wave spectrum shows the spread of spectral energy in different frequencies and direction (Fig. 15). Two well-separated peaks in spectral energy are observed from November to April when the winter monsoon is active.

The wave spectra grouped into different frequency ranges show that the peak frequency of a large number of wave spectra $(\sim 75 \%)$ falls between 0.06 and $0.1 \mathrm{~Hz}$ with an average $H_{\mathrm{m} 0}$ of $0.82 \mathrm{~m}$. The mean wave spectra for different peak frequency ranges show that for all groups, double-peaked wave spectra are observed (Fig. 16). The intensity of the secondary peak increased as the spectral peak frequency shifted from a low to a high frequency. The relative distance between the two peaks of the wave spectrum represented by the quotient between the mean wave period of the swell components and the mean period of the wind-sea part varied from 1.9 to 5.8 with a mean value of 3.6 and the larger values indi- 


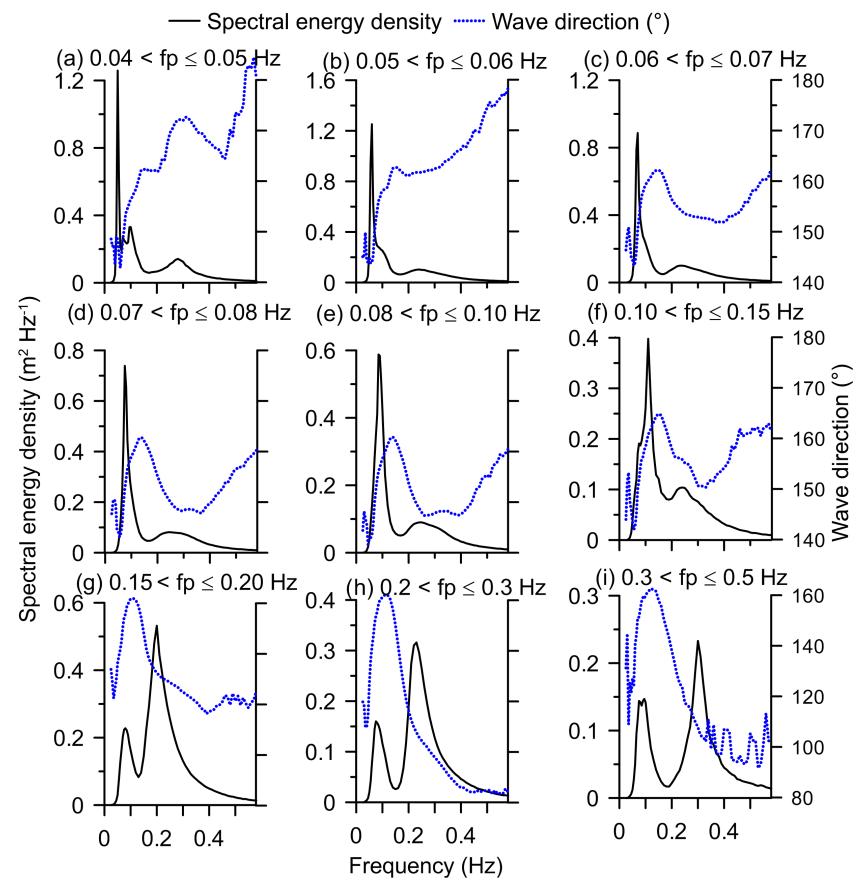

Figure 16. Plot of average spectral energy density and average mean wave direction of waves grouped under different peak frequency bins.

cate more distance between the two peaks of the spectrum. During the study period, the spectral narrowness parameter (v) has an average value of $\sim 0.64$ and is marginally higher $(\sim 0.7$ to 0.9$)$ when a multi-modal wave spectrum consisting of high-frequency local waves and the swells from the south Indian Ocean are present. The values of the spectral peakedness parameter ranged between 2 and 3 for high waves, and most of the time the spectral peakedness parameter tends to be smaller since the spectral energy is distributed across the swell band.

\section{Concluding remarks}

The 1-year measured records of waves show that the waves are lower in the western Gulf of Mannar than in the eastern Arabian Sea, and the variation in the wave height in different seasons is also less in the study area. A total of $53 \%$ of the surface height variance in the study area is a result of swells from the southeast and south and the remainder are wind seas from the east and southeast. The seasonal average swell contribution is less than that observed for other locations around India. For a majority of the time, multi-peaked spectra (58.5\% of the time) are observed. Even though the study area is in a gulf region, since its opening is exactly toward the southwest and the winds also blow from the southwest during the summer monsoon, the monthly mean wave spectrum is swell-dominated in all months, with the exception of December and January during which the wind seas dominate. The percentage of swells in the surface variance decreased as the waves moved from open ocean to bay ( 7 to $8.5^{\circ} \mathrm{N}$ latitude) in all months except August. Over an annual cycle, long-period waves $\left(T_{\mathrm{p}}>14 \mathrm{~s}\right)$ are observed $31.6 \%$ of the time. The wave age of the recorded data is less than 10 during $98 \%$ of the time, signifying that the measured waves are a young sea mixed with swells. An increase in nonlinearity with the increase in significant wave height is not prominent at this location. During 1980-2015, the significant wave height shows a negligible upward trend $\left(2 \mathrm{~cm} \mathrm{yr}^{-1}\right)$.

Data availability. The measured wave data used in the study can be requested from the corresponding author for joint research work. The long-term data on significant wave height and wind speed are from the ERA-Interim global atmospheric reanalysis data set of the ECMWF and are available at http://www.ecmwf.int/en/research/ climate-reanalysis/era-interim (Dee et al., 2011).

Competing interests. The authors declare that they have no conflict of interest.

Acknowledgements. The authors thankfully acknowledge the CSIR, New Delhi, for facilitating the research work and MoES, New Delhi, for the partial financial support given for this research. We thank T. M. Balakrishnan Nair, A. Nherakkol, Jeyakumar, INCOIS, for the help. J. Mohanraj, Kamaraj College, Tuticorin, provided the logistics during data collection and the deployment of the buoy. The deep-water wave data used for comparison of the model results are provided by National Institute of Ocean Technology, Chennai. We thank the editor John M. Huthnance and the two reviewers for the critical comments and suggestions which improved the contents of the paper. This work contributes part of the Ph.D. work of the first author. The authors acknowledge the high-performance computing resources made available at CSIR-NIO for conducting the research reported in this paper. This work has received NIO contribution no. 6087.

Edited by: John M. Huthnance

Reviewed by: two anonymous referees

\section{References}

Amante, C. and Eakins, B. W.: ETOPO1 1 arc-minute global relief model: Procedures, data sources and analysis, NOAA Tech. Memo. NESDIS NGDC-24, Boulder, Colorado, USA, 19 pp., 2009.

Amrutha, M. M. and Sanil Kumar, V.: Spatial and temporal variations of wave energy in the nearshore waters of the central west coast of India, Ann. Geophys., 34, 1197-1208, https://doi.org/10.5194/angeo-34-1-2016, 2016.

Amrutha, M. M., Sanil Kumar, V., and Jesbin, G.: Observations of long-period waves in the nearshore waters of central west coast of India during the fall inter-monsoon period, Ocean Eng., 131, 244-262, https://doi.org/10.1016/j.oceaneng.2017.01.014, 2017. 
Anjali Nair, M. and Sanil Kumar, V.: Wave spectral shapes in the coastal waters based on measured data off Karwar on the west coast of India, Ocean Sci., 13, 365-378, https://doi.org/10.5194/os-13-365-2017, 2017.

Ardhuin, F., Rogers, E., Babanin, A. V., Filipot, J. F., Magne, R., Roland, A., van der Westhuysen, A., Queffeulou, P., Lefevre, J. M., Aouf, L., and Collard, F.: Semiempirical dissipation source functions for ocean waves. Part I: Definition, calibration, and validation, J. Phys. Oceanogr., 40, 1917-1941, 2010.

Arena, F. and Guedes Soares, C.: Nonlinear high wave groups in bimodal sea states, J. Waterway, Port, Coast. Ocean Eng., 135, 69-79, 2009.

Cavaleri, L., Fox-Kemper, B., and Hemer, M.: Wind-waves in the coupled climate system, B. Am. Meteor. Soc., 93, 1651-1661, 2012.

Dee, D. P., Uppala, S. M., Simmons, A. J., Berrisford, P., Poli, P., Kobayashi, S., Andrae, U., Balmaseda, M. A., Balsamo, G., Bauer, P., Bechtold, P., Beljaars, A. C. M., van de Berg, L., Bidlot, J., Bormann, N., Delsol, C., Dragani, R., Fuentes, M., Geer, A. J., Haimberger, L., Healy, S. B., Hersbach, H., Hólm, E. V., Isaksen, L., Kållberg, P., Köhler, M., Matricardi, M., McNally, A. P., Monge-Sanz, B. M., Morcrette, J.-J., Park, B.-K., Peubey, C., de Rosnay, P., Tavolato, C., Thépaut, J.-N., and Vitart, F.: The ERA-Interim reanalysis: Configuration and performance of the data assimilation system, Q. J. Roy. Meteor. Soc., 137, 553-597, 2011.

Donelan, M. A., Dobsen, F. W., Smith, S. D., and Anderson, R. J.: On the dependence of sea surface roughness on wave development, J. Phys. Oceanogr., 23, 2143-2149, 1993.

Glejin, J., Sanil Kumar, V., Balakrishnan Nair, T. M., and Singh, J.: Influence of winds on temporally varying short and long period gravity waves in the near shore regions of the eastern Arabian Sea, Ocean Sci., 9, 343-353, https://doi.org/10.5194/os-9-3432013, 2013.

Glejin, J., Sanil Kumar, V., Amrutha, M. M., and Singh, J.: Characteristics of long-period swells measured in the in the near shore regions of eastern Arabian Sea, Int. J. Nav. Arch. Ocean Eng., 8, 312-319, https://doi.org/10.1016/j.ijnaoe.2016.03.008, 2016.

Goda, Y.: Numerical experiments on wave statistics with spectral simulation, Report Port and Harbour Research Institute, Japan, 9, 3-57, 1970.

Gowthaman, R., Sanil Kumar, V., Dwarakish, G. S., Soumya, S. M., Singh, J., and Ashok Kumar, K.: Waves in Gulf of Mannar and Palk Bay around Dhanushkodi, Tamil Nadu, India, Curr. Sci. India, 104, 1431-1435, 2013.

Hanson, J. L. and Phillips, O. M.: Wind sea growth and dissipation in the open ocean, J. Phys. Oceanogr., 29, 1633-1648, 1999.

Hasselmann, S., Hasselmann, K., Allender, J. H., and Barnett, T. P.: Computations and parameterizations of the nonlinear energy transfer in a gravity-wave spectrum, Part II: parameterizations of the nonlinear energy transfer for application in wave models, J. Phys. Oceanogr., 15, 1378-1391, 1985.

Hemer, M. A., Church, J. A., and Hunter, J. R.: Variability and trends in the directional wave climate of the Southern Hemisphere, Int J. Climatol., 30, 475-491, 2010.

Henrique, R., Babanin, A. V., Schulz, E., Hemer, M. A., and Durrant, T. H.: Observation of wind-waves from a moored buoy in the Southern Ocean, Ocean Dynam., 65, 1275-1288, 2015.
Hwang, P. A., García-Nava, H., and Ocampo-Torres, F. J.: Dimensionally consistent similarity relation of ocean surface friction coefficient in mixed seas, J. Phys. Oceanogr., 41, 1227-1238, 2011.

IMD: Deep Depression over the Bay of Bengal (08-10 November 2015): A Report, Cyclone Warning Division, India Meteorological Department, New Delhi, http://www.rsmenewdelhi.imd.gov.in/images/pdf/publications/ preliminary-report/DD_08112015.pdf (last access: 10 December 2016), 2015.

Johnson, G., Sanil Kumar, V., and Balakrishnan Nair, T. M.: Monsoon and cyclone induced wave climate over the near shore waters off Puduchery, south western Bay of Bengal, Ocean Eng., 72, 277-286, https://doi.org/10.1016/j.oceaneng.2013.07.013, 2013.

Kuik, A. J., Vledder, G. P., and Holthuijsen, L. H.: A method for the routine analysis of pitch and roll buoy wave data, J. Phys. Oceanogr., 18, 1020-1034, 1988.

Longuet-Higgins, M. S.: Statistical properties of wave groups in a random sea state, Phil. T. R. Soc. Lond. A, 312, 219-250, 1984.

Longuet-Higgins, M. S.: Eulerian and Lagrangian aspects of surface waves, J. Fluid Mech., 173, 683-707, 1986.

Lygre, A. and Krogstad, H. E.: Maximum entropy estimation of the directional distribution in ocean wave spectra, J. Phys. Oceanogr., 16, 2052-2060, 1986.

McComb, P., Johnson, D., and Beamsley, B.: Numerical model study to reduce swell and long wave penetration to Port Geraldton, Proceedings of the 2009 Pacific Coasts and Ports Conference, Wellington, New Zealand, 16-18 September 2009, 1-6 pp., 2009.

Nayak, S., Bhaskaran, P. K., Venkatesan, R., and Dasgupta, S.: Modulation of local wind waves at Kalpakkam from remote forcing effects of Southern Ocean swells, Ocean Eng., 64, 23-35, 2013.

Patra, A. and Bhaskaran, P. K.: Temporal variability in windwave climate and its validation with ESSO NIOT wave atlas for the head Bay of Bengal, Clim. Dynam., 1-18, https://doi.org/10.1007/s00382-016-3385-z, 2016.

Patra, S. K., Mishra, P., Mohanty, P. K., Pradhan, U. K., Panda, U. S., Ramana Murthy, M. V., Sanil Kumar, V., and Balakrishnan Nair, T. M.: Cyclone and monsoonal wave characteristics of northwestern Bay of Bengal: long-term observations and modeling, Nat. Hazards, 82, 1051-1073, https://doi.org/10.1007/s11069-016-2233-0, 2016.

Portilla, J., Ocampo-Torres, F. J., and Monbaliu, J.: Spectral Partitioning and Identification of Wind Sea and Swell, J. Atmos. Ocean. Technol., 26, 107-122, 2009.

Sanil Kumar, V., Anand, N. M., Kumar, K. A., and Mandal, S.: Multipeakedness and groupiness of shallow water waves along Indian coast, J. Coast. Res., 19, 1052-1065, 2003.

Sanil Kumar, V., Glejin, J., Dora, G. U., Sajiv, P. C., Singh, T., and Pednekar, P.: Variations in near shore waves along Karnataka, west coast of India, J. Earth Syst. Sci., 121, 393-403, https://doi.org/10.1007/s12040-012-0160-3, 2012.

Sanil Kumar, V., Dubhashi, K. K., Balakrishnan Nair, T. M., and Singh, J.: Wave power potential at few shallow water locations around Indian coast, Curr. Sci. India, 104, 1219-1224, 2013.

Sanil Kumar, V., Dubhashi, K. K., and Balakrishnan Nair, T. M.: Spectral wave characteristics off Gangavaram, Bay of Bengal, 
J. Oceanography, 70, 307-321, https://doi.org/10.1007/s10872014-0223-y, 2014.

Sanil Kumar, V., Shanas, P. R., and Dubhashi, K. K.: Shallow water wave spectral characteristics along the eastern Arabian Sea, Nat. Hazards, 70, 377-394, https://doi.org/10.1007/s11069-0130815-7, 2014.

Sundar, V.: Wave characteristics off the South East Coast of India, Ocean Eng., 13, 327-338, 1986.

Thompson, W. C., Nelson, A. R., and Sedivy, D. G.: Wave group anatomy of ocean wave spectra, Proceeding of 19th conference on Coastal engineering, Am. Soc. Civil Eng., 1, 661-677, 1984.

Toffoli, A., Onorato, M., and Monbaliu, J.: Wave statistics in unimodal and bimodal seas from a second-order model, Eur. J. Mech. B-Fluids, 25, 649-661, 2006.

Tolman, H. L.: A third-generation model for wind waves on slowly varying, unsteady, and inhomogeneous depths and currents, J. Phys. Oceanogr., 21, 782-797, 1991.
Tolman, H. L.: User manual and system documentation of WAVEWATCH-III version 4.18, NOAA/NCEP, Tech. Note, Maryland, USA, 311 pp., 2014.

USACE: Shore Protection Manual, Department of the Army, U.S. Corps of Engineers, Washington, DC, 3-81-3-84, 1984.

Whittaker, C. N., Raby, A. C., Fitzgerald, C. J., and Taylor, P. H.: The average shape of large waves in the coastal zone, Coast. Eng., 114, 253-264, 2016.

Wyrtki, K.: Oceanographic atlas of the international Indian Ocean expedition, Washington, DC, National Science Foundation, 1531, 1971.

Young, I. R., Zieger, S., and Babanin, A. V.: Global trends in wind speed and wave height, Science, 332, 451-455, 2011. 